DOI: $10.24193 /$ tras.62E.8

Published First Online: 02/25/2021

\title{
UNIVERSITIES AS 'DRIVERS' OF LOCAL AND REGIONAL DEVELOPMENT
}

\author{
Marius Constantin PROFIROIU \\ Maria-Roxana BRIȘCARIU
}

\author{
Marius Constantin PROFIROIU \\ Professor, Department of Administration and Public \\ Management, Faculty of Administration and Public \\ Management, \\ Bucharest University of Economic Studies, Bucharest, \\ Romania
}

Tel.: 0040-721-373.101

E-mail: profiroiu@gmail.com

\section{Maria-Roxana BRIȘCARIU}

Assistant professor, Department of Administration and Public Management, Faculty of Administration and Public Management,

Bucharest University of Economic Studies, Bucharest, Romania

E-mail: roxana.briscariu@gmail.com

\section{Abstract}

The society based on knowledge and innovation brings to the fore the role of universities as research and learning spaces, with the purpose for sustainable development at local, regional, national and global levels. Following this approach, we explore the capacity of spreading the knowledge and innovation capital in the North-West region of Romania between universities, the private sector and the public sector. Also, the study explores the role taken by the university system in Romania, locally and regionally, emphasizing what type of relationship defines the exchange of outputs and what are the most useful know-how transfer mechanisms from universities to the private and public sectors.

The empirical research in this paper has shown that there is a growing relationship between universities - private sector - public sector, which is characterized as 'in an incipient phase', 'based on urgent needs of the parties'. All of the actors involved in this triad want to develop the links between universities - private sector - public sector in communication, research, innovation and technology, and they suggest standardization and regulation of this interaction and developing a legal framework to correspond to the actual needs at local and regional levels.

Keywords: universities, public sector, private organization, regional development, knowledge transfer. 


\section{Introduction}

The Knowledge Revolution redefines the development equation and places education, together with human and intellectual capital, and social and institutional capital, at the center of the development strategies (Gal, 2002).

The different perspectives brought more meanings to the concept of education, as the functionalism of Durkheim (1925) and Parsons (1961), in which education was society's transmitter for norms and values (apud Haralambos and Holborn, 2008), the modern and postmodern perspective, where the educational system is the transmitter in terms of economic growth (see Hassink, 2005; Goddard and Kempton, 2011), sustainability (see Stephens et al., 2008; Zilahy and Huisingh, 2009; Andrews, 2015), production and knowledge transfer (see Florinda, 1995; Cooke and Leydesdorff, 2006; Geuna and Muscio, 2009), innovation (see Youtie and Shapira, 2008; Runiewicz-Wardyn, 2013) and democracy (see Arbo and Benneworth, 2007; Mullin, Kotval and Cooper, 2012).

The tendency to change the educational policy, the massification of the educational process, to offer access and to attract a more numerous public became one of the mechanisms through which society copes with the global changes at all levels (Geuna and Muscio, 2009; Haralambos and Holborn, 2008, Curaj et al., 2015). According to Lindberg (2007), the extended participation in higher education and continuous learning in developed and developing countries, in the last decades, determined a bigger interest for the decisional factors in the transition process, from the student to the employer, the so called 'education to work' phenomenon.

In this scenario, the universities became main governing characters, as Florida (1995) and Sternberg (2014) endorse, with the capacity to offer expertise and specific knowledge, know-how exchange (Sedlacek, 2013; Viitanen, Markkula and Soler, 2013), thus contributing to the durable regional development due to the partners' network (local, national, international) and the civic society. Zilahy and Huisingh (2009) observe that, based on empiric evidence, the universities' interest and the regional ones can fully benefit from the communication and cooperation potential among the four characters: students - graduates - employers - universities. Reinforcing the universities' role in knowledge transfer is an important factor, Wise and Wilkinson (2016) considering the regional universities as being a 'driver' for regional innovation. The universities' role to produce knowledge and expertise has a major role in the economic development based on knowledge and innovation, capital which in turn has become a spatial differentiator for sustainability and progress. Asheim and Coenen (2006) have shown the impact of the territorial factors on production growth and on the innovative capacity in a shared space.

Considering the theoretical approaches, we want to analyze the capacity of spreading the knowledge and innovation capital in the North-West region of Romania between universities, private sector and public sector. This paper also offers a comprehensive image of the role taken by the university system in Romania, locally and regionally, emphasizing what type of relationship defines the changes of outputs 
and what are the most useful know-how transfer mechanisms from universities towards other sectors and vice versa.

The main objectives are: $\mathrm{O} 1$. To analyze the theoretical approaches concerning the relevance of universities in regional development as a spatial vector that facilitates innovation and knowledge for the local private sector and public sector; O2. To identify the mechanisms and types of networks through which universities, economic agents and government interact at regional level, explicitly in the North-West region of Romania.

The paper is structured in five sections, the first part explores the literature, especially the relationship between universities - private sector - public sector, relationship found in the literature as 'triple helix', 'knowledge triangle', or 'regional innovation system', and the role of universities in this triad at the local and regional level. The analysis of the impact of universities in local and regional development brings to the fore another concept, 'regional learning', which makes the transition from an abstract triad, that does not have any delimitation, to a spatially delimited form. The second section refers to the conceptual framework that defines the empirical research, with five dimensions being defined: general contextual; legal framework; communication and network; know-how transfer; and future potential; these dimensions are used to analyze the relationship between universities - private sector - public sector, in the local and regional context, at the level of the North-West region. The third section explains the methodology and data that was used for empirical framework in a qualitative manner and in the fourth section we discuss the results using the structure of five dimensions. The last part is summarizing the main findings and furthers the discussion from the perspective of our results.

We endorse this approach as relevant for adapting public policies to the needs and changes in society, starting from the micro to the macro level. Communication and knowledge exchange can be made extremely fast from the local level to the regional level and further to the national level, so that each entity in this process benefits from the best practice. The bottom-up approach is useful to respond to the requirements and particularities that each entity has, such as those at the local level, and which finally correspond with regional needs. We reinforce the statement from which we started, namely to highlight the role of universities in this process, which is desirable and contributes through many more mechanisms, other than the traditional economic and social roles, to local and regional development.

\section{Literature review}

\subsection{Theoretical approaches of university-private sector-public sector triad}

In the past, universities were renowned for keeping a certain distance from local and national governments and towards other social institutions, but this thing changed with the evolution of student numbers, larger public investments for scientific research and the appearance, after the 1990s, of the innovation policy, factors which determined the rise of the influence of the higher education and served as a 
boost to develop collaboration among these and other society stakeholders (Ciolan et al., 2015). Thus, nowadays, the universities are trying to overcome the old model based only on science and to realize that their role in society is much more complex and that they need to approach, as part of society's sustainable development, areas such as healthcare, the environment and transgenerational problems (Goddard and Puukka, 2008).

One of the models which suggest analyzing the relationship between universities and regional development is the model based on the university affiliation, the public sector and the private organizations, a partnership called 'Triple Helix'. This is a phrase introduced by Etzkowitz and Leydesdorff $(1998,2000)$ through which the universities' role in economic development is understood as the interactions and interdependence between universities, private sector and government, intermediated by the capacity of the individuals to go from one sphere to another. The 'Triple Helix' model, defined like this at the beginning, was based on three main characters: universities, private organizations, and the public sector (Leydesdorff and Etzkowitz, 1998). The founders of this paradigm discussed more models: an interventionist model, which came from the classic model in which universities and the private sector were a part of the state, and the relationships between them were supervised by the state; the 'laissez-faire' model, in which relationships were separated between the three characters, each one having a direct relationship with the other, but never all three together; and the 'Triple Helix' model that came with a new approach, all three characters finding themselves in a common space developed under the name of 'tri-lateral networks and hybrid organizations' (Etzkowitz and Leydesdorff, 2000).

The 'Triple Helix' model is an orientation that validates the knowledge and innovation capital of the interregional groups with the desire to develop governing structures that will ensure the planned and systematic coordination between public and private organizations and the universities at a regional level (Asheim and Coenen, 2006; Christopherson and Clark, 2010).

Markkula and Kune (2015) underline six principles through which the 'Triple Helix' paradigm harmonizes the ecosystem of regional innovation:

- characters from the three entities: universities, private sector and public sector;

- structures and networks, with a focus on research and collaboration;

- premises, with referral to social, virtual and physical development;

- new organizations (also called hybrid), that represent an extra innovation through technological and scientific incubators;

- knowledge and technology transfer and co-creation, as they integrate this knowledge capital with the universities, research institutes, private sector and public sector;

- policy, with a reference to taxation and regulating new instruments.

An assessment of these principles shows the absence of citizens as characters in the cohesion model among universities, public and private organizations. 
Afterwards, the 'Triple Helix' model was used to develop a new concept, the 'knowledge triangle' (Viitanen, Markkula and Soler, 2013), that configures a triad between research - education - innovation. This triangle invites us to a synergy and collaboration among the stakeholder groups at regional level in order to become sustainable in the global competition and to support the idea of a 'regional innovation system' (Markkula şi Kune, 2015; Serbanică, 2011). The regional innovation system, concept developed by Morgan (1997), targets the existing relationships between the characters involved in territorial networks that become viable when at least two subsystems are noticed due to the interaction and knowledge transfer (apud Hassink, 2001; Cooke, 2001). According to Cooke (2001), the regional innovation system includes: companies from industrial clusters, regions, including support industries, universities, colleges, training centers, development and research centers, technology transfer agencies, business associations, financial institutions, end the interaction of these characters.

Opposed to the 'Triple Helix' model, which is a concept with an essential vision towards the relationship between universities, industry and government and which does not locate this partnership in a space unit, the 'regional innovation system' paradigm is placed into a determined space and associated with the regional territorial unit. Todtling (2006) develops the concept of regional innovation system through four dimensions associated to the universities that have a role in this process: 'antenna' for adapting exterior knowledge and a mediator for the local knowledge circuit; the source for future high qualified employees; supplier of knowledge in the university - industry relationship; incubator for hybrid academic companies.

\subsection{Aim and impact of universities in regional development}

Over the last years, the number of regional development stimulation initiatives has increased all over the world. Although these initiatives are different based on their aims, objectives and major characteristics, most of them have been designed to encourage sustainable economic growth in order to help low developed regions reach the level of high developed regions and to bring changes for communities. Such initiatives are frequently based on the sustainable growth principle and are designed to combine the economic, social and environmental objectives (Zilahy and Huisingh, 2009, p. 1058).

Universities are the highest forms of education from the scientific, knowledge and innovation points of view, and these characteristics highlight their role at regional level. As stated at the beginning of this work, the global openness tendency of universities and their involvement in the community's life define the universities through three main functions: education, research and governance, according to Sedlacek (2013). These three functions have a direct impact on the universities' ability and potential to promote sustainable growth at regional level. The above-mentioned author correlates the three functions with the development of human capital, the development of social capital and the economic development at regional level. 
Both specialized literature and practical experience show that higher education institutions contribute to the regional development initiatives in several ways. The OECD's project, entitled 'Supporting the Contribution of Higher Education Institutions to Regional Development', reviewed 14 regions throughout 12 countries in order to identify the most important interdependencies between regions and universities and other higher education institutions (Goddard and Puukka, 2008). The study highlighted the key actors in regional development from the historical point of view. Therefore, it was found that, while the economic policy following the World War II was focused on reducing disparities between regions by using regional political interventions, the last two decades and a half are characterized by the birth of regional development and innovation policies which embraced the concept of 'learning regions' (Florida, 1995; Shaw and Allison, 1999; Hassink, 2001; Christopherson and Clark, 2010; Hassink, 2010), industrial clusters or knowledge clusters (see Hassink, 2005; Wise and Wilkinson, 2016). In addition, Rosenbaum (2006) endorses the developing relationship between the private sector and civil society with the mean to deliver better public goods and services to the citizens. This type of development also had an impact on the role of the universities, which included the transfer of the research done by the academic institutions to private organization and administrative entities, offering consulting services and building regional capacity (Yusuf and Nabeshima, 2006; De Fuentes and Dutrénit, 2012).

The phrase 'learning region' was developed and conceptualized in the 1990s, when the increase in globalization processes led to a need for developing solutions at regional level (Rutten and Boekema, 2009). Florida (1995) describes the "learning region' as a concept working as 'collectors and repositories of knowledge and ideas, and provide the underlying environment or infrastructure which facilitates the flow of knowledge, ideas and learning' (p. 528). The learning regions are based on three main elements which overlap: regional learning, groups and networks, and innovation institutions. Rutten and Boekema give us the following definition for regional learning: 'It pertains to the transfer, creation, absorption and implementation of knowledge among regional partners, which, in turn, triggers innovation and regional renewal' (2007, p. 136). On the other hand, studies on clusters and networks give us perspectives on the organizational aspects of learning, and the studies on innovation institution define the support infrastructure for learning and innovation.

The 'learning region' concept has become a popular approach for resuming the characteristics of the places which successfully respond to the challenges brought by a knowledge-based economy (Cooke and Leydesdorff, 2006; Huggins, 2010). The regional higher education institutions are at the core because of their role regarding the human resource development and research-based innovation (Christopherson and Clark, 2010). There are analyses which identified other characteristics of the learning regions, such as: academic feature which encourage the researchers to engage in practical activities and does not resist to the creation of a link between the academic community and the business environment; a local financial community willing and 
capable to offer funds for start-up companies; and expertise in local entrepreneurship for start-up businesses (Yusuf and Nabeshima, 2006; Jongbloed, 2008).

Starting from the structure proposed by Florida (1995), which highlights by comparison the learning regions vs. the mass production regions, we are proposing a continuation of the comparison by new indicators specific for the actual reality and which highlight the main characteristics of regional development and innovation. Table 1 illustrates the new indicators adapted to the initial dimensions, but specific to the way the knowledge-based economy developed, and the industry as we knew it traditionally takes new forms. As this chronological parallelism shows, we notice an increasing individualization of the economic processes, an increased focus on the human and knowledge capital and inter- and intra- relationships with more levels (local, regional, national, international). The interregional relations do not replace the type relations, national relations, international relations, they come as a form of cohesion and consensus by which they strengthen and consolidate the progress of the region.

Regarding the studies carried out in Romania about the role of universities in regional development, this topic has not been extensively researched in this context. An analysis in this direction with a quantitative perspective being based on statistical data at the macro level was conducted by Șerbănică, Constantin and Drăgan (2015). Their study analyzed macro indicators corresponding to 90 public and private universities in Romania. The analysis has been based on a composite index by which they measure the knowledge transfer between universities and private sector in the eight regions of Romania. The data obtained show that there is an unequal distribution of universities and that the Bucharest-Ilfov region excels in terms of input, financial and human resources, but obtains a low result compared to the other regions. The NorthWest region has a balanced profile and is the second in terms of knowledge transfer index between universities and private sector, and the third in terms of the regional innovation potential. The authors notice a major involvement of the universities in the North-West region, which explains the development of research and innovation at regional level (Șerbănică, Constantin and Drăgan, 2015).

\section{Conceptual framework}

In order to analyze the diffusion of knowledge and innovation capital in the North-West region between universities, public and private sector, the conceptual framework has been developed to reach two main objectives, as shown below: O1. The first objective was to analyze the theoretical approaches concerning the relevance of universities in regional development as a spatial vector that facilitates the innovation and knowledge for the local private sector and public sector; O2. The second objective is to identify the mechanisms and types of networks through which universities, economic agents and government interact at regional level, explicitly in the North-West region. 


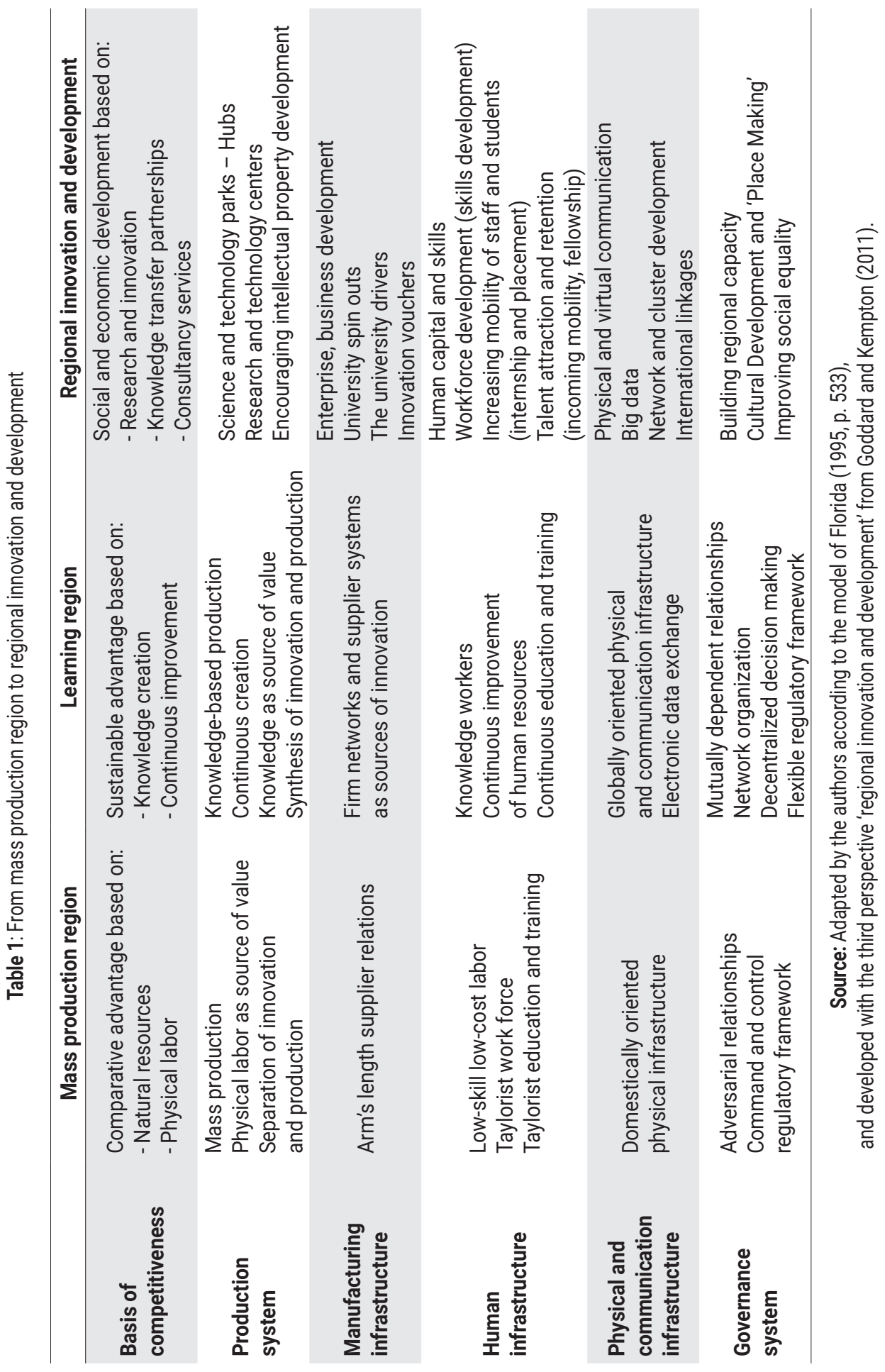


Based on the proposed objectives, the empirical analysis aims the exploration of five dimensions (Figure 1): general contextual; legal framework; communication and network; know-how transfer; future potential.

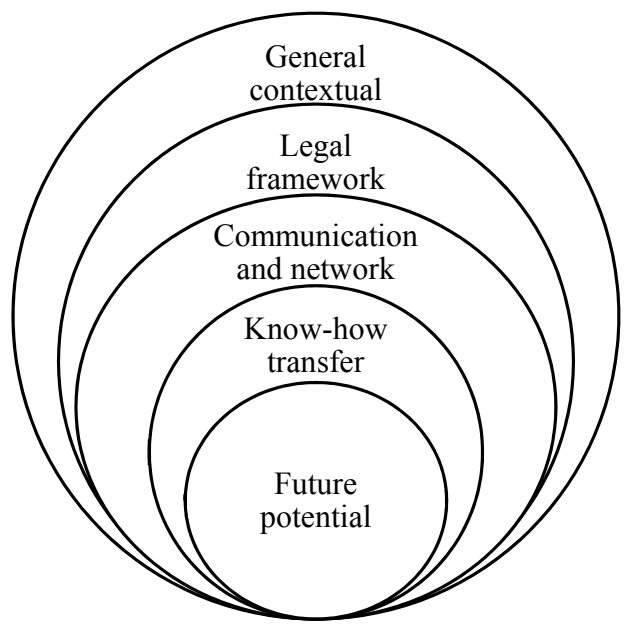

Figure 1: Dimensions used in the qualitative analysis

Source: Authors' elaboration

General contextual aspects are investigated from the perspective of the concepts that have established a triad between universities, private sector and public sector; i.e. Triple Helix (Leydesdorff and Etzkowitz, 1998), knowledge triangle (Viitanen, Markkula and Soler, 2013) and learning regions (Florida 1995; Shaw and Allison, 1999; Christopherson and Clark, 2010; Hassink, 2010). The purpose of the empirical analysis from the perspective of this dimension is to identify the way in which universities, public and private sector coexist in the North-West region, how the three relate to each other and what are the mechanisms among them. The legal framework refers to the dissemination of legislation, rules and norms at the level of the three entities through which they function as active partners at regional level. Another aspect is the analysis of the applicability of the legislation in force on the concrete reality at regional level and the legal levers that support this triad. Communication and network is another important component in maintaining a vivid relation among the three institutional structures that form the economic nucleus at spatial level. This dimension looked at the communication channels used by the representatives of the three structures - universities, public and private sector - that facilitate the exchange of information, but develop and consolidate social networks among these three vectors. The know-how transfer method tried to identify if there is knowledge exchange, technology exchange, practices and aptitude exchange between universities and how they are materialized. This dimension encompasses the diffuse and abstract exchange, which is hard to measure but exists and contributes under many forms to the social 
and economic development in a practical space, in this case in the North-West region. Future potential, the last dimension, was developed in order to identify the unused potential in this university - private sector - public sector triad.

\section{Research methodology}

\subsection{Aim, objectives and research questions}

The purpose of the study is to explore the capacity of spreading the knowledge and innovation capital in the North-West region among universities, private sector and public sector. Also, we aim to underline the role taken by the university system locally and regionally in Romania, emphasizing what type of relationship defines the exchange of outputs and what are the most useful know-how transfer mechanisms from universities to private sector and public sector.

The main objectives are:

O1. To analyze the theoretical approaches concerning the relevance of universities in regional development as a spatial vector that facilitates the innovation and knowledge for the local private sector and public sector;

O2. To identify the mechanisms and types of networks through which universities, economic agents and government interact at regional level, namely in the North-West region.

Taking into consideration the literature review and conceptual framework we develop the following research questions:

Q1. What is the stage of collaboration among universities - private sector - public sector and what kind of exchanges is it based on?

Q2. How does the legal framework support the partnership relations among universities - private sector - public sector?

Q3. What kind of relationships exist in the triad universities - private sector public sector and how do these entities communicate with each other?

Q4. What are the mechanisms through which know-how is exchanged among universities - private sector - public sector?

Q5. How can the collaboration relations be developed in the universities - private sector - public sector triad?

\subsection{Research design and data collection}

This study used a qualitative approach, the design of the research being to investigate in depth a specific topic, the analysis was conducted via two workshops and semi-structured interviews (Babbie, 2010). The qualitative approach of this study highlights the depth peculiarities in the relationship among universities, private sector and public sector, in the North-West region of Romania. Following the main objectives and research questions we developed, through this study we want to enrich 
the meaning and forms of know-how transfer among universities, private sector and public sector, with evidence from a specific sample in the North-West region.

Participants at the two workshops were invited with a well-defined purpose from specific institutions corresponding to the three entities: universities, the private sector/economic agents and the public sector, from the North West region. One workshop took place in Oradea and the other one in Cluj-Napoca, and a total of 109 participants attended from universities (professors, students, alumni and representatives of the university management); private organizations and NGOs (through representatives with strategic and management roles); public sector (public servants, decision-makers in local and regional administrations). The main characteristics of the participants were to have relevant expertise and knowledge regarding the topic. The two workshops were held within the project called 'Mecanism de comunicare și participare la procesul decizional realizat privind implicarea universităților în procesul de dezvoltare regional' (in English, Communication and participation mechanism in the decision-making process regarding the involvement of universities in the regional development process) - SIPOCA 3, organized by the Romanian Ministry of Education and Research. The workshops were led by Marius Constantin Profiroiu, were recorded and were structured based on a discussion guide that included questions such as: 'How do you see the role of universities in the community? What should the relationship among universities and the private sector, respectively public sector, entail?; What are the most important elements on which the relationship between the university and the community is based?; What are the main connectors of communication and networking and how do they work in the community?; What do you think should be done and by whom in order to improve the relationship between universities and socio-economic environment?'.

The eighteen semi-structured interviews were conducted with representatives of the three entities: universities - private sector - public sector, six interviews for each. Part of the interviews were conducted face to face, and the others online, following the interview guide that included questions with open answers, created for exploratory purposes. Both the interview guide and the workshop guide were organized from a general context to a specific context, focused on issues and needs in the relationship among the three. The questions touched on topics such as the patterns in the existing relationships, the exemplification of the practices used, the needs of each of the entities involved, and getting to the projections, namely how they see the development of these relationships and by whom.

\subsection{Defining the empirical framework}

The North-West region includes 6 counties: Bihor, Bistrița-Năsăud, Cluj, Maramureș, Satu-Mare and Sălaj, with a surface of 34,159 square kilometers and a population of 2,836,304 inhabitants in 2017 (analysis based on data provided by the Romanian National Institute of Statistics (INS)). It is the second most important region from the economic growth point of view; the regional gross domestic product 
calculated according to CON103I - GDP by micro-regions, development regions and counties - calculated according to CAEN Rev.2 for 2017, reaches a GDP of 104,848.90 million RON (analysis based on data provided by INS). It is important to mention that the North-West region is the second most important region, after the Bucharest-Ilfov region (the capital of Romania), for the first time in the recent history.

\section{Main findings and discussion}

The main findings of the study are structured using the five dimensions from the conceptual framework, and the synthesis is done by analyzing the qualitative data collected during the two workshops and the semi-structured interviews conducted with participants from the social and economic environment, universities and public sector in the North-West region.

The general contextual aspects defining the relationships and mechanisms among universities, the socio-economic environment and the public sector highlighted a generalized image which is common for all the actors involved, both the workshop attendants and the interviewed persons. The connections between the actors are made based on the purpose of each side and they represent partnerships that mostly aim to ensure internships for students, recruiting workforce needed by the social economy actors, debates/workshops, specific educational programs, technical expertise and local development projects. In the North-West region, besides the above-mentioned partnerships, there are initiatives based on research, know-how transfer and development of public policies in partnership.

We notice a convergence of the empirical evidence, the actors involved in interactions at the level of the North-West region having similar opinions on how the mutual influence takes place in the universities - private sector - public sector triad. Data highlighted the lack of a clear structure of action at the regional level, and that the way in which the universities are grouped and act in relation to the regional economic agents is based on immediate goals. The current relationship among universities - private sector - public sector is characterized as 'still at the beginning level', 'in an incipient phase', 'based on urgent needs of both parties, employers need employees (immediately!), and universities need resources, especially financial, urgently'.

In conclusion, there is a lack of standardization and regulation of the interaction among the main actors, a long-term strategy is needed at the regional level in this respect and the decision factor in this relationship is missing. Initiatives exist and are desired by all actors, but are viewed as exceptions rather than regularities.

With regard to the legal framework, the two workshops revealed a series of dysfunctions of the legislation in the field, the representatives of the university management invoking the legislation that exclusively stimulates 'scientific research'/publication of scientific articles, not encouraging in any form teaching activities related to the development of interactions, communication and relationships among universities - social economy actors and the private sector. A deficiency mentioned by the employers refers to the legislation in force, which discourages the employers to get 
involved in organizing internships for longer periods, and the communication and collaboration between the mentioned parties is scripted, without actual support (material, logistical and informational). Guests reported the lack of a legislative framework to support and encourage long-term partnerships based on research, expertise, technology exchange. All the actors agreed that the relationship between universities and the socio-economic environment should be rethought in terms of the law of sponsorship and fiscal facilities, the legislative framework should encourage the development of research partnerships between universities and economic agents. This change of the legislative framework has been proposed to allow the economic agents to finance teaching activities, research and innovation projects.

Another component debated and agreed by all the actors involved was to increase the quality of the internships. Besides the legislative and administrative aspects of regulation, the interregional character is defined by two other proposed characteristics: a double feedback system and an evaluation system. In order to increase the professionalism of the internships, an integrating system is needed with double feedback: an evaluation of the students by the internship partner (employer), and an evaluation of the student regarding the agreement of the activities assumed by the internship partner (employer). The interviews and workshops revealed that there are dissatisfactions both from the employers regarding the involvement of the students, but also from the students regarding the commitment of the internships partners. In conclusion, in the opinion of the participants, the legal framework does not correspond to the actual realities in the region and in society, internships have to be better organized, and updated according to the needs of the actors involved.

Communication and network - we notice a rather informal character of the communication and networks between the actors, the connections being of an indirect nature, facilitated by the immediate purposes. The same communication channels are chosen (direct and indirect communication), with similar frequencies, the communication mediating the relations between universities and private sector, and universities and public sector. This analysis was channeled through the link between economic agents and the public sector through universities, and did not explore directly the public - private partnership (see Mina-Raiu, 2014). The qualitative analysis of the data revealed that the purpose underlying the communication and networks between the three entities, university - private sector - public sector, is to exchange information and use each other's resources. In this context, each actor becomes a transmitter and receiver, where each party takes on the most available resource that the other can provide without too much effort.

The forms of communication used by universities and private sector in the NorthWest region to transmit and to receive information to and from the main actors with which they relate are diversified, using both classical communication channels such as displays, leaflets, flyers, as well as modern channels based on modern technologies such as websites, integrated information platforms, official website, social-media networks, discussion groups. In addition to the ones listed above, direct meetings are 
held either with students, or with teachers, and also workshops and debates. These types of direct initiatives are sporadic and diffuse at an early 'incipient' stage, according to one of the students who attended the workshop. Also, one of the employers appreciated such initiatives, but believes that 'they sum up the first level, the second level at most, in a series of concentric circles'. Similar to the legislative framework, the participants appreciate the intentions of developing communication networks between universities, economic agents and public servants, but consider that these 'unilateral initiatives focused on specific fields of study or specific for some faculties, do not have any implications emphasized at the regional level, numerically speaking'.

For employers, the actor who should initiate, manage, set the direction and develop the communication networks among university - private sector - public sector is the academic environment which is considered the pillar that unites the three groups of interests.

Know-how transfer - empirical data support the paradigm of Sedlacek (2013) and Viitanen, Markkula and Soler (2013), that the university - private sector - public sector Triple Helix contributes through the exchange of know-how to sustainable regional development, thanks to the network between partners (local, national, international) and civil-society actors. The representatives of the private sector stated that universities show an openness for the private sector - university partnership, and although this partnership is not very advanced, different projects have been exemplified in the North-West region: the development of professional master programs with the socio-economic environment; 10-year partnerships at the Technical University of Cluj-Napoca; representation of IT companies in the Technical University Advisory Board; the project developed in 2015 by BBU, entitled 'The interaction of the university with the business environment', involving representatives of the economic environment. Some of the representatives of the private sector present at the debate also mentioned: international master programs specializing in the technical field, based on the relationship with the business environment - at the Technical University of Cluj-Napoca; the organization of the Advisory Council at the University of Oradea, an inter-institutional collaboration in the scientific and cultural field between the University of Oradea and Oradea City Hall; internship programs organized by commercial banks via BBU; organizing artistic events for employers and students at the University of Arts, via the Career Information, Guidance and Counseling Center.

The know-how process between employers and universities is highlighted by the employers' representatives through: training partnerships, public debates, employer presentations in faculties, sponsorships, private scholarships, job fairs, internships. The know-how exchange generally represents an exchange of resources, and is not too developed from the research, innovation, expertise, public policy and technology point of view.

Future potential - the participants of the study concluded that the triad universities - private sector - public sector is necessary and has many advantages for all the actors involved as we detailed below. 
The relationship among social economy actors (public organizations, private organizations, NGOs) and universities should be seen as a bilateral relationship, according to a commercial representative who considers the interaction between the actors mentioned above to be vital. The advantages of the universities from the partnership with the social economy actors is considered by one of the respondents as a source of innovation in research and technology:

'universities could find out in real time what are the needs and changes in the labor market, what are the latest discoveries in research done by the private environment or what are the needs of the private environment in terms of research; [...] finding out the global labor market trends, but also of the trends in research and innovation'.

Another benefit is the contribution of social economy actors with financial, human, technological and/or know-how resources in the development of educational and research programs. At the same time, the social economy actors consider the potential bilateral partnerships with the academic environment as useful for recruiting future employees, promoting the employer brand, accessing the network of local, national or international partners, finding out information about future employees or the educational and research trends in universities. Finally, the complexity of the interaction and the mechanisms identified among the three entities can be essentially illustrated as in Figure 2, where we can notice direct and indirect links between the main types of resources that are interchangeable among universities - private sector - public sector, based on the empirical data collected.

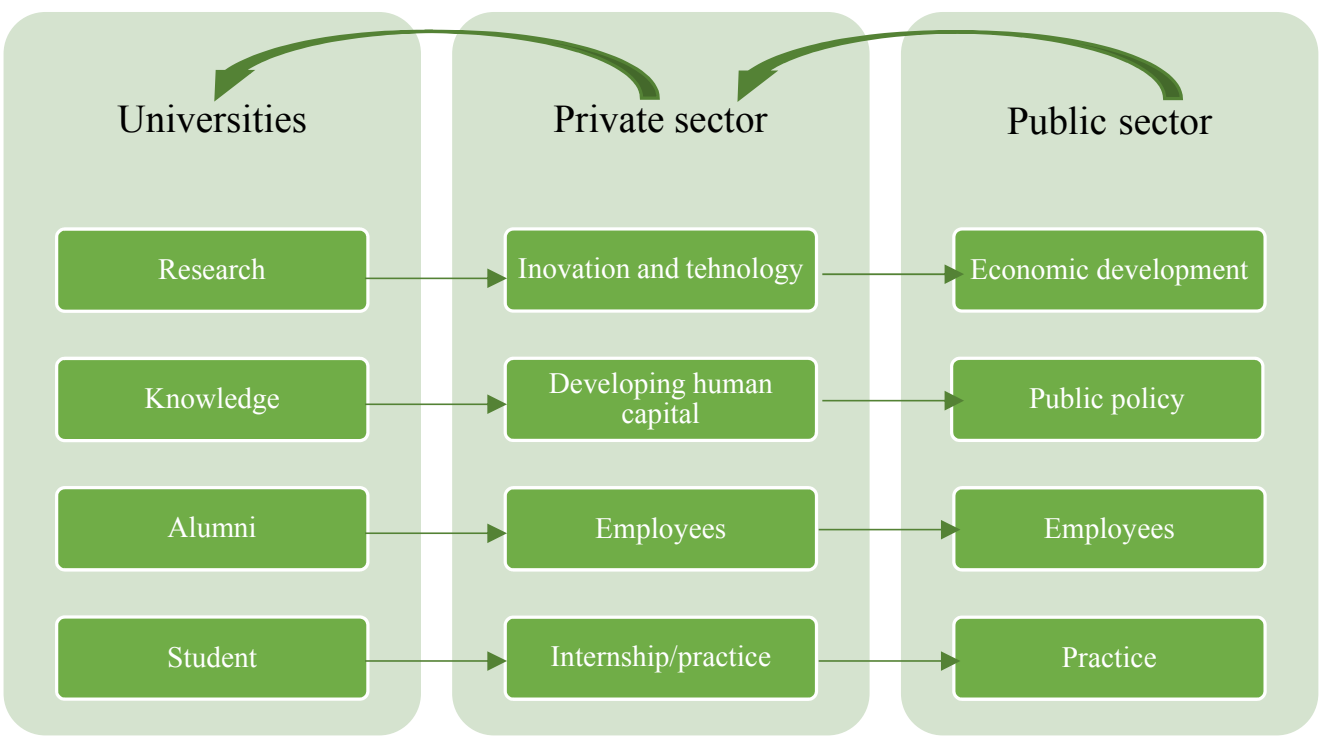

Figure 2: The 'connectors' in the regional triad

Source: Authors' elaboration 


\section{Conclusions}

The know-how transfer in innovation and technology is a key element for development and growth in any field, and that is why this study highlights once more the importance of universities in local and regional development. The research results bring clarity to the role that universities have in regional development and in understanding the nature of the relationship among universities - private sector public sector. The analysis shows an ability to adapt and reinvent the aggregate entities, through alternative forms of interaction, in the absence of a legal framework, to achieve results and goals for each part.

Going back to the purposes of the present research, to outline a holistic picture of the knowledge transfer process among the main actors at regional level, the study revealed principal relations and transfers in the university - private sector - public sector triad. The transfer of scientific and technological knowledge at regional, national and international level is an important factor of economic growth, which is why the development of a theoretical-methodological model at regional and national level is useful mainly for practical reasons. Changing the perception of research and innovation is probably the most elaborate step, but also the most important to facilitate the dialogue among universities and the private and public sector.

The transfer of knowledge and innovation in Romania can be facilitated and should be facilitated by the government agenda in the alignment with the European recommendations, an aspect that is not yet found in the current legislative framework; as mentioned above, the transfer of knowledge is carried out occasionally and not through a structural framework. Local and regional decision-makers are the main actors interested in this research's results, as they are the ones who can request and promote legal and financial support from the national government, but also the Ministry of National Education, as governmental representative, has to be concerned about this data. As the analysis showed, universities are seen as pillars in this triad, being suggested that they should be the ones to manage local and regional relations and interests in knowledge, technology and innovation transfer. In order for universities to be reference pillars in the university - private sector - public sector triad, it is necessary to develop public policies in this regard, with the participation of all actors involved, and to find a better agreement for each entity. Agreement between national, regional and local decision-makers is needed to support a cross-national technology and innovation transfer and to contribute to sustainable socio-economic development, both at regional and national level.

\section{References:}

1. Andrews, D., 'The Circular Economy, Design Thinking and Education for Sustainability', 2015, Local Economy, vol. 30, no. 3, pp. 305-315.

2. Arbo, P. and Benneworth, P., 'Understanding the Regional Contribution of Higher Education Institutions', 2007, OECD Education Working Papers, no. 9, OECD Publishing, [Online] available at https://www.oecd-ilibrary.org/docserver/161208155312.pdf?expires 
$=1613320418 \& \mathrm{id}=\mathrm{id} \&$ accname $=$ guest $\&$ checksum =0E16F586CAC92B16534A00583E361696, accessed on December 15, 2020.

3. Asheim, B.T. and Coenen, L., 'Contextualising Regional Innovation Systems in a Globalising Learning Economy: On Knowledge Bases and Institutional Frameworks', 2006, The fournal of Technology Transfer, vol. 31, no. 1, pp. 163-173.

4. Babbie, E., Practica cercetării sociale [The Practice of Social Research], Iași: Polirom, 2010.

5. Christopherson, S. and Clark, J., 'Limits to 'The Learning Region': What UniversityCentered Economic Development Can (and Cannot) Do to Create Knowledge-Based Regional Economies', 2010, Local Economy, vol. 25, no. 2, pp. 120-130.

6. Ciolan, L., Păunescu, M., Fartuşnic, C., Iucu, R. and Hintea, C., 'The Role of Impact Evaluation in Evidence-Based HE Policy Making: The Contribution of Transparency Tools', in Curaj, A., Deca, L., Egron-Polak, E. and Salmi, J. (eds.), Higher Education Reforms in Romania. Between the Bologna Process and National Challenges, Springer, 2015, pp. 25-42.

7. Cooke, P. and Leydesdorff, L., 'Regional Development in the Knowledge-Based Economy: The Construction of Advantage', 2006, The Journal of Technology Transfer, vol. 31, no. 1, pp. 5-15.

8. Cooke, P., 'Regional Innovation Systems, Clusters and the Knowledge Economy', 2001, Industrial and Corporate Change, vol. 10, no. 4, pp. 945-974.

9. Curaj, A., Deca, L., Egron-Polak, E. and Salmi, J. (eds.), Higher Education Reforms in Romania. Between the Bologna Process and National Challenges, Springer, 2015.

10. De Fuentes, C. and Dutrénit, G., 'Best Channels of Academia - Industry Interaction for Long-term Benefit', 2012, Research Policy, vol. 41, no. 9, pp. 1666-1682.

11. Etzkowitz, H. and Leydesdorff, L., 'The Dynamics of Innovation: From National Systems and 'Mode 2' to a Triple Helix of University - Industry - Government Relations', 2000, Research policy, vol. 29, no. 2, pp. 109-123.

12. Florida, R., 'Toward the Learning Region', 1995, Futures, vol. 27, no. 5, pp. 527-536.

13. Gal, D., Educaţia şi mizele ei sociale [Education and Its Social Stakes], Cluj-Napoca: Dacia, 2002.

14. Geuna, A. and Muscio, A., 'The Governance of University Knowledge Transfer: A Critical Review of the Literature', 2009, Minerva, vol. 47, no. 1, pp. 93-114.

15. Goddard, J. and Kempton, L., Connecting Universities to Regional Growth: A Practical Guide, Brussels, 2011.

16. Goddard, J. and Puukka, J., 'The Engagement of Higher Education Institutions in Regional Development: An Overview of the Opportunities and Challenges', 2008, Higher Education Management and Policy, vol. 20, no. 2, pp. 11-41.

17. Haralambos, M. and Holborn, M., Sociology: Themes and Perspectives, Harper Collins UK, 2008.

18. Hassink, R., 'Locked in Decline? On the Role of Regional Lock-ins in Old Industrial Areas', in Boschma, R. and Martin, R. (eds.), The Handbook of Evolutionary Economic Geography, Cheltenham, UK: Edward Elgar Publishing, 2010, pp. 450-468.

19. Hassink, R., 'How to Unlock Regional Economies from Path Dependency? From Learning Region to Learning Cluster', 2005, European Planning Studies, vol. 13, no. 4, pp. 521-535.

20. Hassink, R., 'The Learning Region: A Fuzzy Concept or a Sound Theoretical Basis for Modern Regional Innovation Policies?', 2001, Zeitschrift für Wirtschaftsgeographie, vol. 45, no. 1, pp. 219-230. 
21. Huggins, R., 'Regional Competitive Intelligence: Benchmarking and Policy-Making', 2010, Regional Studies, vol. 44, no. 5, pp. 639-658.

22. Jongbloed, B.W.A., 'Indicators for Mapping University - Regional Interactions', 2008, [Online] available at http://www.prime-noe.org/spip.php?action=acceder_document\&arg $=436 \& \mathrm{cle}=24212 \mathrm{f} 819 \mathrm{a} 676$ bf0b6a49b18e794874c53ed6b80\&file=pdf\%2FJongbloed.pdf, ac cessed on December 8, 2018.

23. Leydesdorff, L. and Etzkowitz, H., 'The Triple Helix as a Model for Innovation Studies', 1998, Science and Public Policy, vol. 25, no. 3, pp. 195-203.

24. Lindberg, M.E., 'At the Frontier of Graduate Surveys', 2007, Higher Education, vol. 53, no. 5, pp. 623-644.

25. Markkula, M. and Kune, H., 'Making Smart Regions Smarter: Smart Specialization and the Role of Universities in Regional Innovation Ecosystems', 2015, Technology Innovation Management Review, vol. 5, no. 10, pp. 7-15.

26. Mina-Raiu, L., 'Public-Private Partnership Impact on Local Economic Development. Evidence from Romanian Counties', 2014, Proceedings of Administration and Public Management International Conference, vol. 10, no. 1, pp. 198-210.

27. Mullin, J., Kotval-K., Z. and Cooper, J. 'The University and Local Economic Development', 2012, Transylvanian Review of Administrative Sciences, Special Issue, pp. 126-136.

28. Rosenbaum, A., 'Cooperative Service Delivery: The Dynamics of Public Sector - Private Sector - Civil Society Collaboration', 2006, International Review of Administrative Sciences, vol. 72, no. 1, pp. 43-56.

29. Runiewicz-Wardyn, M., 'The Role of Knowledge Absorption and Innovation Capability in the Technological Change and Economic Growth of EU Regions', 2013, International Journal of Management and Economics, vol. 39, no. 1, pp. 51-69.

30. Rutten, R. and Boekema, F., 'The Learning Region: A Conceptual Anatomy', in Rutten, R. and Boekema F. (eds.), The Learning Region: Foundations, State of the Art, Future, Cheltenham, UK: Edward Elgar, 2007, pp. 127-142.

31. Rutten, R. and Boekema, F., 'Universities and Regional Development', 2009, Regional Studies, vol. 43, no. 5, pp. 771-775.

32. Sedlacek, S., 'The Role of Universities in Fostering Sustainable Development at the Regional Level', 2013, Journal of Cleaner Production, vol. 48, pp. 74-84.

33. Șerbănică, C.M., Constantin, D.L. and Drăgan, G., 'University - Industry Knowledge Transfer and Network Patterns in Romania: Does Knowledge Supply Fit SMEs' Regional Profiles?', 2015, European Planning Studies, vol. 23, no. 2, pp. 292-310.

34. Șerbănică, C., 'A Cause and Effect Analysis of University-Business Cooperation for Regional Innovation in Romania', 2011, Theoretical and Applied Economics, vol. 18, no. 10, pp. 29-44.

35. Shaw, J.K. and Allison, J., 'The Intersection of the Learning Region and Local and Regional Economic Development: Analysing the Role of Higher Education', 1999, Regional Studies, vol. 33, no. 9, pp. 896-902.

36. Stephens, J.C., Hernandez, M.E., Román, M., Graham, A.C. and Scholz, R.W., 'Higher Education as a Change Agent for Sustainability in Different Cultures and Contexts', 2008, International Journal of Sustainability in Higher Education, vol. 9, no. 3, pp. 317-338. 
37. Sternberg, R., 'Success Factors of University-Spin-offs: Regional Government Support Programs Versus Regional Environment', 2014, Technovation, vol. 34, no. 3, pp. 137-148.

38. Tödtling, F., 'The Role of Universities in Innovation Systems and Regional Economies', Presentation at the Expert Meeting on 'The Future of Academic Research' (OECD Workshop), October 19-20, 2006, Vienna, [Online] available at https:/www.oecd.org/ innovation/research/37592074.pdf, accessed on December 15, 2020.

39. Viitanen, J., Markkula, M. and Soler, C.R., 'Systemic Development of Regional Innovation Ecosystems - Modernizing the Triple Helix', in Lappalainen, P. and Markkula, M. (eds.), The Knowledge Triangle: Re-Inventing the Future, European Society for Engineering Education SEFI, 2013.

40. Wise, G. and Wilkinson, S., 'How Regional Universities Drive Regional Innovation', 2016, [Online] available at https://www.industry.gov.au/sites/g/files/net3906/f/May\%202018/do cument/other/how_regional_universities_drive_regional_innovation.docx, accessed on February 10, 2019.

41. Youtie, J. and Shapira, P., 'Building an Innovation Hub: A Case Study of the Transformation of University Roles in Regional Technological and Economic Development', 2008, Research Policy, vol. 37, no. 8, pp. 1188-1204.

42. Yusuf, S. and Nabeshima, K., How Universities Promote Economic Growth, World Bank, 2006.

43. Zilahy, G. and Huisingh, D., 'The Roles of Academia in Regional Sustainability Initiatives', 2009, fournal of Cleaner Production, vol. 17, no. 12, pp. 1057-1066. 